\begin{tabular}{|c|l|}
\hline Title & A verage Crack Spacing of Overlay-Strengthened RC Beams \\
\hline Author(s) & Zhang, Dawei; Ueda, Tamon; Furuuchi, Hitoshi \\
\hline Citation & $\begin{array}{l}\text { Journal of Materials in Civil Engineering, 23(10), 1460-1472 } \\
\text { https:/doi.org/10.1061/AS SCE)MT.1943-5533.0000316 }\end{array}$ \\
\hline Issue Date & 2011-10 \\
\hline Doc URL & http://hdl.handle.net/2115/47705 \\
\hline Type & article (author version) \\
\hline File Information & JMCE23_10_1460-1472.pdf \\
\hline
\end{tabular}

Instructions for use 


\section{Average Crack Spacing of Overlay-strengthened RC Beams}

Dawei Zhang ${ }^{\text {a) }}$, Tamon Ueda ${ }^{\text {b) }}$, Hitoshi Furuuchi ${ }^{\text {() }}$

a) Postdoctoral Fellow, Lab of Engineering for Maintenance System, Faculty of Engineering, Hokkaido University. Nishi 8 Kita 13, Kita-Ku, Sapporo 060-8628, Japan. Email: david@eng.hokudai.ac.jp Tel:+81-11-706-6220; Fax: +8111-707-6582

b) Professor, Lab of Engineering for Maintenance System, Faculty of Engineering, Hokkaido University, Japan. Email: ueda@eng.hokudai.ac.jp

c) Assistant Professor, Lab of Engineering for Maintenance System, Faculty of Engineering, Hokkaido University, Japan. Email: jin@eng.hokudai.ac.jp

Abstract: The research is focused on evaluating the average crack spacing of overlay-strengthened reinforced concrete $(\mathrm{RC})$ beams. The current equations in different structural codes for predicting the average crack spacing of $\mathrm{RC}$ beam with multilayered-reinforcing bars is proved to be inapplicable for overlay-strengthened RC beam, although these two kinds of beams are both with reinforcement in multi-layers. Therefore, a simple, practical and new analytical model that is capable of predicting the average crack spacing of overlay-strengthened beams is developed. An overlay-strengthened beam element is analyzed based on equilibrium and compatibility equations to formulate the average stresses of concrete, overlay and tension reinforcement. A series of verification comparisons with the experimental investigations, which involved various types of beam elements, are performed to verify the validity and reliability of the model. The proposed model performs satisfactorily with respect to measured response from the experimental database.

Keyword: crack spacing; overlay; strengthening; interface; bond; multilayered-reinforcement 


\section{Background}

Overlaying is considered as a major retrofitting method for flexural and fatigue strengthening or retrofitting of concrete flexural members. As illustrated in Fig. 1, in this method, the tension reinforcements such as steel bars or Fibre-Reinforced Plastic (FRP) grid are arranged underneath the lower surface of the concrete members and the Polymer Cement Mortar (PCM) or High Performance Fiber Reinforced Cementitious Composites (HPFRCC) is sprayed onto them. In light of the weak bond strength of overlaying with normal cement based materials, the PCM or HPFRCC offers a good compromise of bond strength and durability. Comparing with steel bars as overlay reinforcement, the FRP grid is of low weight and high corrosion resistance and gaining more and more interests recently.

Cracks in overlay-strengthened RC structures may be expected because of the relatively low tensile strength of concrete and overlay materials and the use of high strength reinforcement in substrate and overlay. Cracking in overlay-strengthened RC structures has a major influence on structural performance, including tensile, bending and shear stiffness, energy absorption capacity, ductility and corrosion resistance of reinforcement. Moreover, the average crack spacing of overlaystrengthened beams plays an important role in transferred shear stress along overlay-substrate interface and normal stress generated in the substrate concrete in case when the premature debonding failure is investigated (Zhang et al. 2010; Wang and Ling 1998; Raoof and Hassanen 2000). It is, therefore, necessary to predict the cracking behavior of overlay-strengthened RC beam. 
Despite the fact that many design models have been provided by different structural codes or individual researchers with respect to average crack spacing of RC members with single or multilayered-reinforcement (JSCE 2007; EC2 2004; CSA 2004; NS 1992; CEB-FIP 1990; Broms 1965; Albandar and Mills 1974; Bặzant and Oh 1983; Rizk and Marzouk 2010; Dawood and Marzouk 2010; Marzouk et al. 2010; Rizkalla et al. 1983; Rizkalla and Hwang 1984), which are similar to overlay-strengthened RC member with reinforcement layers in the substrate and overlay, their applicability for overlay-strengthened beams has not yet been investigated.

The main objective of this study is to develop a rational methodology for predicting the average crack spacing of overlay-strengthened RC beam. Firstly, the predicted average crack spacing based on existing models from several design specifications is compared with that from experimental database. Then a model which is capable of evaluating crack behaviors of both overlaystrengthened beam and conventional RC beam was developed. The analytical approach is based on equilibrium and compatibility equations to formulate the average stresses of concrete, overlay and reinforcement of an overlay-strengthened beam element.

2. Crack spacing approach in the different structural codes

Tensile cracking in reinforced or prestressed concrete members is affected by various factors, such as the types of reinforcement, concrete cover, effective cross sectional area of concrete, diameter of reinforcement, ratio of reinforcement, number of layers of reinforcement, surface geometry of 
reinforcement, quality of concrete, magnitude of prestress, etc. Generally, all or some of these parameters are induced in different structural codes.

\subsection{JSCE 2007}

The value of crack spacing in JSCE (2007) is stated by the following equations:

$S_{c r}=1.1 k_{1} k_{2} k_{3}\left\{4 C+0.7\left(c_{s}-\phi\right)\right\}$

where $C$ debones concrete cover in $\mathrm{mm}, c_{s}$ and $\Phi$ denote center-to-center distance and diameter of outer-layer tensile reinforcement in $\mathrm{mm}$. $k_{1}$ is coefficient that characterizes the effect of surface geometry of reinforcement ( $=1.0$ for deformed bars, and $=1.3$ for plain bars and prestressing steel), $k_{2}$ is a constant to take into account the effect of concrete quality, which may be calculated as

$k_{2}=\frac{15}{f^{\prime}{ }_{c}+20}+0.7$

where $f_{c}{ }_{c}$ is compressive strength of concrete in $\mathrm{MPa} . k_{3}$ is a constant to take into account the effect of multiple layers of tensile reinforcement and may be calculated as

$$
k_{3}=\frac{5(n+2)}{7 n+8}
$$

where $n$ is number of the layers of tensile reinforcement.

\subsection{Eurocode EC2 provisions}

In the Eurocode EC2 (2004), the average crack spacing is evaluated from the following expression: 
$S_{c r}=2 C+k_{1} k_{2} \frac{\phi A_{c t}}{A_{s t}}$

where $C$ denotes concrete cover in $\mathrm{mm} ; \Phi$ is diameter of outer-layer tensile reinforcement in $\mathrm{mm}$; $A_{s l} / A_{c t}$ denotes effective reinforcement ratio with $A_{s l}=$ the area of tensile reinforcement and $A_{c l}=$ the effective concrete area (see Fig. 2.a). $k_{1}=0.8$ for deformed bars and 1.6 for plain bars, and $k_{2}=0.5$ for bending and $=1.0$ for pure tension. In this approach, the EC2 code takes only the effect of the concrete cover and ignores the influence of the bar spacing of the outer-layer tension reinforcement.

\subsection{CSA S474 2004}

According to Canadian offshore code CSA-S474 (2004), the average crack spacing of cracks normal to the reinforcement may be calculated using the following equation:

$S_{c r}=2.0(C+0.1 S)+k_{1} k_{2} \phi / \rho_{t N s}$

where $C$ denotes concrete cover thickness in $\mathrm{mm}$ (not greater than $55 \mathrm{~mm}$ ); $S$ denotes bar spacing of the outer-layer tension reinforcement in $\mathrm{mm} ; k_{1}$ is coefficient that characterizes bond properties of bars $\left(=0.4\right.$ for deformed bars, and $=0.8$ for plain bars); $k_{2}$ is coefficient to account for strain gradient $=0.25\left(\varepsilon_{1}+\varepsilon_{2}\right) / 2 \varepsilon_{1}, \varepsilon_{1}$ and $\varepsilon_{2}$ are the largest; and smallest tensile strains in the effective embedment zone; $\Phi$ is bar diameter of the outer-layer tension reinforcement in $\mathrm{mm}$. $\rho_{t N s}$ is the effective reinforcement ratio, which may be calculated by

$$
\rho_{t N s}=A_{s t} / h_{e f f} b
$$


where $h_{\text {eff }}$ is effective embedment thickness in mm, taken as the greater of $\left(a_{1}+7.5 \Phi^{\prime}\right)$, and $\left(a_{2}+7.5 \Phi\right)$, but not greater than the height of tension zone (see Fig. $\left.2 . b\right) ; b$ is width of the section in $\mathrm{mm} ; A_{s t}$ is area of reinforcement within the effective embedment thickness in $\mathrm{mm}^{2}$.

\subsection{NS 3473 E 1992}

The Norwegian code NS-S474E (1992) provides the similar approach for the calculation of the average crack spacing as that of CSA-S474 (2004), with only a small difference in the calculation of $k_{2}$ and effective reinforcement ratio $\rho_{t N s}$. as shown in Fig. 2.c.

\subsection{CEB-FIP 1990 provisions}

The value of the crack spacing in CEB-FIP (1990) code is stated by a different expression from previous codes (JSCE 2007; EC2 2004; CSA 2004; NS 1992) as:

$$
\begin{aligned}
& S \max =\frac{2}{3} l_{s, \max } \\
& l_{s, \max }=\frac{\phi_{s}}{3.6 \rho_{s, e f}}
\end{aligned}
$$

where $l_{\text {smax }}$ is the length over which slip occurs between the steel reinforcement and concrete, $\Phi_{s}$ denotes the diameter of the outer-layer tension reinforcement in $\mathrm{mm}, P_{s, e f}$ is the effective reinforcement ratio, which can be calculated as

$$
\rho_{s, e f}=\frac{A_{s}}{A_{c, e f}}
$$

where $A_{s}$ denotes the area of steel bars and $A_{c, e f}$ is the effective area of concrete in tension as indicated in Fig. 2.a. 


\section{Applicability of current models}

3.1 Comparison between calculation and experimental results

In order to exam the applicability of the models in different structural codes, the calculated crack spacing with different codes equations should compare with the experimental crack spacing of overlay-strengthened RC beams. For this purpose, published or reported experimental results of overlay-strengthened beams with sufficient dimension and material parameters as well as average crack spacing are analyzed (Furuuchi et al. 2000; Furuuchi et al. 2002; Matsumoto 2000; Satoh and Kodama 2005;Zhang 2009; Zhang et al 2009; Yamamoto 2010; Yamamoto et al. 2010). In total, 36 samples with different material properties and dimensions are collected, in which 26 samples are PCM overlay with steel bars, 8 samples are HPFRCC overlay with FRP grid and 2 samples are PCM overlay with FRP grid. All the test data included in this data base were obtained for simply supported rectangular RC beams subjected to four-point bending load and the average crack spacing is taken as the average spacing of flexure cracks between two upper loading points (constant moment zone). The geometrical and material properties of the collected samples are summarized in Appendix A. The average crack spacing measured at each sample in which the steel bars are used as reinforcement in overlay is presented in Table 1 and Fig. 3 along with numerical estimations based on current models from different codes. The mean value and standard deviation of $S_{\text {cal }} / S_{\text {exp. }}$ are shown in Table 1 as well.

The JSCE code equation overestimates the value of average crack spacing with mean value of $S_{\text {cal. }} / S_{\text {exp. }}$ equaling to1.14 and the other four code equations underestimate the value of average crack 
spacing with mean value of $S_{c a l} / S_{\text {exp. }}$ ranging from 0.66 to 0.76 . Moreover, big scatters can be observed for all the code equations with standard deviation ranging from 0.19 to 0.30 . Generally speaking, none of the code equations can give reasonable agreement to measured average crack spacing of overlay-strengthened RC beam. Therefore, the current models in different codes for estimating average crack spacing of RC beam with multilayered-reinforcement can not be applied directly for overlay-strengthened RC beams, although these two kinds of beams are both with reinforcement in multi-layers.

\subsection{Explanations on the mismatch}

The equations in different design codes for multilayer-reinforced beam should have been verified to be applicable before they are induced as a design approach. The reason why they are incapable of predicting the average crack spacing overlay-strengthened beams needs to be clarified.

Fig. 4 shows the strain distributions across the depth of the cross section of overlay strengthened beam. By assuming that the overlay and the substrate behave monolithically, the moment at the initiation of tensile crack in substrate $\left(M_{c c}\right)$ and overlay $\left(M_{c o}\right)$ can be calculated respectively as:

$$
\begin{array}{ll}
M_{c c}=\frac{I_{c}}{h_{c}-x_{g}} f_{t c} & \text { (substrate) } \\
M_{c o}=\frac{E_{c}}{E_{o}}\left(\frac{I_{c}}{h_{o}-x_{g}}\right) f_{t o} & \text { (overlay) }
\end{array}
$$

where $f_{t c}$ and $f_{t o}$ denote the tensile strength of concrete and overlay material, $E_{c}$ and $E_{o}$ denote the Young's modulus of concrete and overlay material, $x_{g}$ denotes the neutral axis depth of uncracked 
section of overlay strengthened beam and $I_{c}$ denotes the second moment of transformed area of the uncracked cross section in terms of concrete. The ratio between $M_{c c}$ and $M_{c o}$ is then expressed as:

$$
R_{c}=\frac{M_{c c}}{M_{c o}}==\frac{E_{o}\left(h_{o}-x_{g}\right) f_{t c}}{E_{c}\left(h_{c}-x_{g}\right) f_{t o}}
$$

For conventional beam with multilayered-reinforcement $\left(E_{c}=E_{o}, f_{t c}=f_{t o}\right)$, the value of $R_{c}$ is always greater than 1, which means the tensile crack always initiates near to the outer-layer reinforcement. While in case of the overlay strengthened beam samples as shown in appendix $\mathrm{A}\left(E_{c}>E_{o}, f_{t c}\left\langle f_{t o}\right)\right.$, the maximum value of $R_{c}$ is 0.52 with a mean value of 0.45 , which means the tensile crack always initiates from the substrate concrete. This agrees with the experimental observations as well.

Most of the present research work and existing analytical models for predicting cracking behavior of beams with multilayered-reinforcement consider only the effects of the diameter and spacing of outer-layer reinforcement, which is nearest to the initiation location of tensile crack. However in case of overlay-strengthened beam, the cracks tend to initiate from the substrate concrete and propagate towards the overlay, as a result of relative high tensile strength and low Young's modulus of overlay materials. Therefore, it is reasonable that the properties of reinforcement in the substrate instead of overlay should be used in the equations of different codes. Table 2 and Fig. 5 show the calculated average crack spacing by using the diameter and spacing of tension reinforcement in the substrate, comparing with experimental results. Much better agreements can be achieved with modified models from CSA (2004), NS (1992), EC2 (2004) and CEB-FIP (1990), but there is no apparent improvement with modified models from JSCE (2007), since both the diameter and the 
spacing of reinforcement are dominant in CSA (2004), NS (1992), EC2 (2004) and CEB-FIP (1990), but not in JSCE (2007). However it is not confident enough to apply this substitution simply for the valid prediction of average crack spacing of overlay strengthened beam because all the equations in different codes are only empirical models and the cracking mechanism in the overlay-strengthened beam is not clear yet. Moreover, all the existing equations are meant for members with steel reinforcing bars. None of them may be applicable to the overlay strengthened beam with FRP grid as reinforcement in overlay, since steel bar diameters are needed for calculation. An analytical approach considering the stresses of concrete, overlay and reinforcement of overlay strengthened beam element based on equilibrium and compatibility equations is then developed for a better understanding of cracking behavior of overlay strengthened beam with either steel bars or FRP grid as tension reinforcement.

\section{Analytical model}

When a segment of overlay strengthened beam is subjected to uniaxial tension loading which is greater than the cracking load of both substrate concrete and overlay, the idealized cracked beam section is assumed to consist of the effective tensile area of concrete and overlay, and reinforcement in the concrete and overlay as illustrated in Fig. 6.a. For a section between two adjacent cracks, the bond between the concrete or overlay and the reinforcement restrains the elongation of reinforcement, and part of the tensile stress in the reinforcement is transmitted to the concrete or overlay consequently (Satoh and Kodama 2005). 
Fig. 6.a shows a longitudinal segment of overlay strengthened beam between two adjacent cracks subjected to uniaxial tensile force. The length of this segment $S$ represents the crack spacing. The free body diagram of the substrate and overlay elements with length of $d x$ is shown in Fig. 6.b. The equilibrium of forces acting on the concrete and overlay segment can be written as follows:

$$
\left\{\begin{array}{l}
F=F+d F+\sum O_{r} \tau_{b c}(x) d x+\sum O_{s} \tau_{b o}(x) d x \\
\frac{d F}{d x}=-\left(\sum O_{r} \tau_{b c}(x)+\sum O_{s} \tau_{b o}(x)\right) \\
\frac{d \sigma_{c}(x)}{d x} A_{c t}+\frac{d \sigma_{o}(x)}{d x} A_{o t}=-\left(\sum O_{r} \tau_{b c}(x)+\sum O_{s} \tau_{b o}(x)\right)
\end{array}\right.
$$

where $\tau_{b c(x)}$ and $\tau_{b o(x)}$ denote the bond stress at the reinforcement-concrete interface and the reinforcement-overlay interface at the stabilized crack stage, which is assumed to follow a parabolic variation as shown in Fig. 6.c. The peak bond stress $\tau_{b c m}$ or $\tau_{b o m}$ occurs at the midsection between the two zero points. This bond stress distribution closely agrees with the experimental observations according to Jiang et al. (1984) and Kankam (1997). $O_{r}$ and $O_{s}$ denote the perimeter of reinforcement in concrete and overlay respectively, $A_{c t}$ and $A_{o t}$ denote the effective tension area of concrete and overlay. For a certain steel bar or FRP grid, the maximum area of the reinforced concrete $\left(A_{\text {cmax }}\right)$ or overlay $\left(A_{\text {omax }}\right)$ zone within which stable crack can develop is,

$$
A_{c(o) \max }=\frac{A_{s(F)} \cdot f_{y(F y)}}{f_{c(o) t}}
$$


where $A_{s(F)}$ and $\left.f_{y(F y}\right)$ denote the area, the yielding strength of steel bar (FRP Grid) respectively, $f_{c(o) t}$ is the tensile strength of concrete (overlay). In a two-dimensional consideration, the maximum size of square bond effective zone for steel bar $\left(h_{\text {cmax }}\right)$ or FRP Grid $\left(h_{\text {omax }}\right)$ can then be calculated as,

$$
h_{c(o) \max }=\sqrt{A_{c(o) \max }}
$$

In case of bending, the maximum height of effective zone should not be higher than the tension area (area which is below the neutral axis) as shown in Fig. 2.d. Moreover, the reduction of concrete tension area due to existence of transverse reinforcements or stirrups is considerably small and ignored in this analysis.

For a given element between two adjacent cracks, the expected location for the maximum concrete or overlay tensile stress is at the midway (zero-slip point). At the stabilized crack stage, the tensile stress of concrete or overlay at the zero-slip point cannot be greater than the tensile strength $f_{c t}$ or $f_{o t}$ respectively, regardless of load increase. This condition corresponds to the stabilized crack spacing $S_{c s}$, for the case in which the concrete tensile stress $\sigma_{c}=f_{c t}$ or $S_{o s}$, for the case in which the overlay tensile stress $\sigma_{o}=f_{o t}$.

Since tensile strains in the substrate concrete and overlay are released after cracking and both concrete and overlay can behave monolithically, we can assume that the concrete and overlay have the same strain $\varepsilon_{o}$ at zero-slip point at the primary crack formation stage under uniaxial tension load, which means 


$$
\varepsilon_{o}=\frac{\sigma_{c s}}{E_{c}}=\frac{\sigma_{o s}}{E_{o}}
$$

where $\sigma_{\text {cmax }}$ and $\sigma_{\text {omax }}$ denote the maximum tensile stress in concrete and overlay at the zero-slip point. Since the substrate and overlay.

Based on Eq. 8 and Eq.11, the following equations can be derived:

$$
\begin{aligned}
& \sigma_{c s} A_{c t}+\sigma_{o s} A_{o t}=\int_{S / 2}^{0}-\left(\sum O_{r} \tau_{b c}(x)+\sum O_{s} \tau_{b o}(x)\right) d x \\
& =\frac{-S\left(\sum O_{r} \tau_{b c m}+\sum O_{s} \tau_{b o m}\right)}{3} \\
& \sigma_{c s}=\frac{S\left(\sum O_{r} \tau_{b c m}+\sum O_{s} \tau_{b o m}\right)}{3\left(A_{c t}+A_{o t} \frac{E_{o}}{E_{c}}\right)} \leq f_{c t} \\
& \sigma_{o s}=\frac{S\left(\sum O_{r} \tau_{b c m}+\sum O_{s} \tau_{b o m}\right)}{3\left(A_{c t} \frac{E_{c}}{E_{o}}+A_{o t}\right)} \leq f_{o t}
\end{aligned}
$$

Stablized crack spacing of substrate concrete layer is then expressed as:

$$
\left.S_{c s}=\frac{3 f_{c t}\left(A_{c t}+A_{o t} \frac{E_{o}}{E_{c}}\right)}{\left(\sum O_{r} \tau_{b c m}+\sum O_{s} \tau_{b o m}\right.}\right)
$$

Stabilized crack spacing of overlay layer is expressed as: 
$S_{o s}=\frac{3 f_{o t}\left(A_{c t} \frac{E_{c}}{E_{o}}+A_{o t}\right)}{\left(\sum O_{r} \tau_{b c m}+\sum O_{s} \tau_{b o m}\right)}$

The bond stress between reinforcement and concrete or overlay depends primarily on the compressive strength, the cover thickness of concrete or overlay, and on the surface condition of reinforcement. Due to the existence of cross ribs in the surface of FRP grid, which has similar function of ribs in the surface of steel bar, the bond properties of overlay-FRP grid interface can be assumed to be similar as that of steel bar-concrete interface. The peak bond stress $\tau_{b c m}$ or $\tau_{b o m}$ as shown in Fig. 6.b is then calculated using the fib Model Code equation (2010) as follows:

$$
\text { in case of splittingfailure } \begin{aligned}
\tau_{b c(o) m} & =5.5 \cdot\left(\frac{f^{\prime}{ }_{c(o)}}{20}\right)^{0.25} \quad \text { with transvese reinforcenent } \\
\tau_{b c(o) m} & =5.0 \cdot\left(\frac{f^{\prime}{ }_{c(o)}}{20}\right)^{0.25} \quad \text { without transterse reinforcenent (16) }
\end{aligned}
$$

in case of pull - out failure $\tau_{b c(o) m}=1.25 \sqrt{f^{\prime}{ }_{c(o)}}$

where $f^{\prime}($ o) denotes the cylinder compressive strength of concrete(overlay).

In beam with small concrete cover and clear spacing between the reinforcement, transverse reinforcement provides the most relevant confining effect, especially in zones far from direct supports where external pressure is not present (Untrauer and Henry, 1965; Gambarova and Rosati, 1997). It is assumed that the confining effect of transverse steel bar or FRP grid in the overlay is similar as that of stirrup in the substrate concrete. 
Once the crack initiates in either layer of concrete or overlay, it will propagate to another layer due to the reduction of stiffness of cracked section, therefore the stabilized crack spacing of overlay strengthened composite $S_{S}$ depends on the lesser of $S_{c s}$ and $S_{o s}$, which means

$S_{s}=\min \left(S_{c s}, S_{o s}\right)$

Considering the effect of strain gradient, the average crack spacing of overlay strengthened beam under flexure load can be predicted as follows:

$S_{s f}=k_{1} \min \left(S_{c s}, S_{o s}\right)$

where $k_{1}$ is the coefficient to account for strain gradient $=\left(\varepsilon_{1}+\varepsilon_{2}\right) / 2 \varepsilon_{1}$ according to CSA S474 (2004), $\varepsilon_{1}$ and $\varepsilon_{2}$ are the largest; and smallest tensile strains in the effective embedment zone as illustrated in Fig. 2.d, $k_{1}$ has the maximum value of 1 in case of uniaxial load and minimum value of

0.5 .

The maximum and minimum crack spacing at the stabilized cracking stage can then be determined by assuming the maximum crack spacing $\left(S_{\text {maxsf }}\right)$ is twice of the minimum crack spacing $\left(S_{\text {minsf }}\right)$ as

$$
\begin{aligned}
& S_{\max s f}=\frac{4}{3} S_{s f} \\
& S_{\min s f}=\frac{2}{3} S_{s f}
\end{aligned}
$$


It should be noted that the proposed model assumes the monolithic responding of overlay and substrate concrete, therefore it is not applicable for the case when debonding between substrate and overlay occurs.

Eqs.13-19 can also be used for conventional RC beam with single or multilayered-reinforcement $\left(E_{c}=E_{o}, f_{t c}=f_{t o}\right)$, both Eq.13 and Eq.14 has same result of average crack spacing as:

$$
S_{s}=\frac{3 k_{1} f_{c t}\left(A_{c t}+A_{o t}\right)}{\tau_{b c m}\left(\sum O_{r}+\sum O_{s}\right)}=\frac{3 k_{1} f_{c t} A_{t}}{\tau_{b c m} \sum O_{r s}}
$$

where $\sum O_{r s}$ denotes the total perimeter of tension reinforcement, and $A_{t}$ denotes the entire efficient tension area.

\section{Verification}

The same database is used for verifying the applicability of proposed analytical model for overlay with steel bars as tension reinforcement. Beside, 10 additional samples with FRP grid as reinforcement in overlay are calculated to verify the applicability of proposed analytical models for overlay with FRP grid as tension reinforcement. Moreover, 8 conventional RC beam samples with single or double layer steel reinforcement and with various dimension and reinforcement ratio as shown in Appendix B are collected in order to verify the applicability of proposed model to the conventional RC beam with single or multilayered-reinforcement. Due to the existence of transverse reinforcement in the overlay of all specimens, Eq.15 is used for calculation of maximum 
bond shear stress of both substrate concrete layer and overlay layer. The calculation results of overlay strengthened beams are shown in Table 2 and Fig. 7.a. The $S_{c s}$ is always smaller than $S_{o s}$ for all the samples because of relative high tensile strength and low Young's modulus of overlay materials, which means the crack of substrate concrete dominates the average crack spacing of overlay strengthened beam. This explains the reason why the developed model can predict the average crack spacing of overlay strengthened beams more precisely than the current structural codes, in which the out-layer (overlay) reinforcements always control. The mean value of $S_{\text {cal. }} / S_{\text {exp }}$. is 1.01 with standard deviation of 0.11 . The comparison between calculation and experiment results of conventional beams with single or multilayered-reinforcement based on existing structural codes or proposed model is shown in Table 3 and Fig. 7.b. The JSCE code (2007) gives the most conservative prediction. The mean value of $S_{c a l} / S_{\text {exp. }}$ is 1.05 with standard deviation of 0.08 by using the proposed model. For either overlay strengthened or conventional RC beam with single or multilayered-reinforcement, the analytical values have a satisfactorily agreement with the experimental values, which verifies the accuracy of the proposed model, indicating that the proposed prediction method is applicable and reliable.

\section{Conclusions}

This paper shows that the current models in different structural codes for estimating average crack spacing of beams with multilayered-reinforcement are inaccurate for overlay-strengthened RC beams with reinforcement layers in both the substrate concrete and overlay, although these two kinds of beams are similar to each other in a sense that the reinforcement is arranged in multilayers. 
The different initiation location of tensile cracks between the substrate concrete and overlay is considered to be one of main explanations on this mismatch. However it is not convincing enough to apply the substitution in the current structural codes simply for the valid prediction of average crack spacing since the cracking mechanism is not clear. Moreover, the existing empirical equations can not be applied for overlay strengthened beam with FRP grid as reinforcement in overlay.

A crack spacing model is then developed by considering the equilibrium and compatibility equations of overlay strengthened beam element. The new model can account for the influence of major parameters, such as the quantities and total perimeters of reinforcement across the crack, the tensile strength of substrate concrete and overlay materials, the characteristics of the bond between the concrete and reinforcement in the substrate and the bond between the overlay materials and reinforcement in the overlay.

To validate the proposed model, the predicted values of the average crack spacing based on the proposed model are compared with series of experimental investigations, which involved various types of beam elements. The proposed model performs satisfactorily with respect to measured response from the experimental work for both steel bars or FRP grid reinforced overlay and conventional RC beam with single or multilayered-reinforcement. Therefore, this model can be applied as a practical way for predicting the accurate average stabilized crack spacing in designing overlay strengthened or conventional RC beams. 
This study is a part of the International Collaborative Research, "Life Cycle Prediction and Management of Concrete Structures" adopted by the Asia-Africa S \& T Strategic Cooperation Promotion Program of Special Coordination Funds for Science and Technology of Japan's Ministry of Education, Culture, Sports, Science and Technology. The authors appreciate the financial aid from Hokkaido University and the Grant-in-Aid for Scientific Research (A) No.22246058. Dr Kouichi Satoh of the Research Institute of Nara Construction Co., Ltd. is sincerely acknowledged for providing the authors with a detail of his test database.

\section{References}

Albandar, F. A-A., and Mills, G. M.(1974). "The prediction of crack width in reinforced concrete beams", Magazine of Concrete Research, V. 26, No. 88, 153-160.

Bặzant, Z. P., and Oh, b. H. (1983). "Crack spacing in reinforced concrete: approximate solution”, Journal of Structural Engineering, ASCE, V. 109, No. 1, 93-108.

Broms, B. B. (1965). "Crack width and crack spacing in reinforced concrete members", Journal of American Concrete Institute, Proceedings, V. 62, No. 10, 1237-1265.

Canadian Standard Associations (2004). S474 concrete structures. Mississauga (Ontario, Canada): Canadian Standard Associations.

Comite Euro-International Du Beton. CEB-FIP model code (1990). Lausanne Swittzerland): Comité EuroInternationale du Beton et Federation Internationale e la Procontrainte.

Dawood, N., Marzouk, H. (2010). "An analytical approach for crack spacing of thick reinforced concrete plates", Engineering Structures 32, 472-482.

EC2, Eurocode 2 ( 2004). Design of concrete structures_Part I: General rules and rules or buildings. Paris: European Committee for Standardization.

Fib model code (2010), first complete draft, bulletin 55/1, International Federation for Structural Concrete.

Furuuchi, H., Kakuta, Y., Nishimuta, K., Shimizu, M. and Tokunaga, T., (2002). "Load carrying capacity of RC beam strengthened with sprayed overlay", proceedings of 57th annual conference of JSCE, v, 619-620 (in Japanese).

Furuuchi, H., Tsuneoka, S., Kakuta, Y. and Yoshizumi, A. (2000). "Research on RC members strengthened with sprayed overlay”, Proceedings of JCI, June, Vol.22, No.1, 523-528 (in Japanese).

Gambarova, P.G., and Rosati, G.P. (1997). "Bond and Splitting in bar Pull-out: Behavioral Laws and Concrete Cover Role". Magazine of Concrete Research, 49(179):99-110.

Jiang, D., Shah, S. P, and Andonian, A. (1984). "Study of the Transfer of Tensile Forces by Bond, ACI Structural Journal, V. 81, No. 3, May-June, 251-259.

JSCE. Standard specification for concrete structures (2007): Design. Japan Society of Civil Engineerings.

Kankam, C., (1997), "Relationship of Bond Stress, Steel Stress, and Slip in Reinforced Concrete," Journal of Structural Engineering, ASCE, V. 123, No. 1, 79-85.

Marzouk, H., Hossin, M.,Hussein, A. (2010), "Crack width estimation for concrete plates", ACI Structural Journal,V. 107, No. 3, 282-290. 
Matsumoto, Y. (2000). "Static and fatigue properties of overlay strengthened beams", Bachelor graduation thesis, Hokkaido University (in Japanese).

Norwegian Council for Building Standardization (1992). NS34773E Concrete structures design rules. Norway: Norwegian Council for Building Standardization.

Raoof, M., Hassanen, MAH. (2000). "Peeling failure of reinforced concrete beams with fibre-reinforced plastic or steel plates glued to their soffits". Proceedings of the Institution of Civil Engineers, Structures and Buildings, 140(August), 291-305.

Rizk, E. and Marzouk, H. (2010). "A new formula to calculate crack spacing for concrete plates", ACI Structural Journal, V. 107, No. 1, 43-52.

Rizkalla, S.H., Hwang, L.S., El-Shahawi, M. (1983). "Transverse reinforcement effect on cracking behavior of R.C. members", Canad Journal of Civil Engineering, 10(4), 556-81.

Rizkalla, S.H., Hwang, L.S. (1984). “Crack prediction for members in uniaxial tension”, ACI Structural Journal, 81(4), 572-9.

Satoh, K. and Kodama, K. (2005). "Central Peeling Failure Behavior of Polymer Cement Mortar Retrofitting of Reinforced Concrete Beams”, Journal of Materials in Civil Engineering, ASCE/ March/April, 126-136.

Untrauer, R.E. and Henry, R.L. (1965). "Influence of Normal Pressure on Bond Strength”, ACI Journal, Proceedings, 62(5): 577-586.

Wang, C.Y., Ling, F.S. (1998). "Prediction model for the debonding failure of cracked RC beams with externally bonded FRP sheets". Proceedings of the Second International Conference of Composites in Infrastructure (ICCI), Arizona, USA, 548-562.

Yamamoto, T. (2010a). "Capacities and failure mode of beam strengthened with HPFRCC and FRP grid under static and fatigue load", Bachelor graduation thesis, Hokkaido University (in Japanese).

Yamamoto, T., Kikuchi, Y., Zhang, D.W., Furuuchi, H., Ueda, T., Tamura, T., Morii, N., Saitoh, T. (2010b). “Static Load and Failure Mode of Beam strengthened with HPFRCC and FRP Grid overlay”, Proc. of Hokkaido Chapter of the JSCE, E-19, February (in Japanese).

Zhang, D.W., Ueda, T., and Furuuchi, H. (2010). "IC debonding of polymer cement mortar (PCM) overlay strengthened RC beam", Journal of Materials in Civil Engineering, ASCE (posted ahead of print).

Zhang, D.W. (2009). "Interface and beam behaviour of PCM-strengthened concrete", PhD graduation thesis, Hokkaido University.

Zhang, D.W., Furuuchi H., Hori A. and Ueda T. (2009). "Fatigue Degradation Properties of PCM-concrete Interface", Journal of Advanced Concrete Technology, JCI, Vol. 7, No. 3, 425-438.

Zhao, W.J., Maruyama, K. (1994). "Experimental study on flexural cracking of RC beams with multi-layers of longitudinal bars", Journal of Materials, Concrete Structures and Pavement, JSCE, No. 490, V-23, 137-145. 
Figure Caption List

Fig. 1 Typical view of overlay strengtheing

Fig. 2 Effective embedded area

Fig. 3 Comparison with original current equations

Fig. 4 Sectional analysis of overlay strengthened beam

Fig. 5 Comparison with modified current equations

Fig. 6 Element analysis of composite

Fig. 7 Comparison with new proposed model 


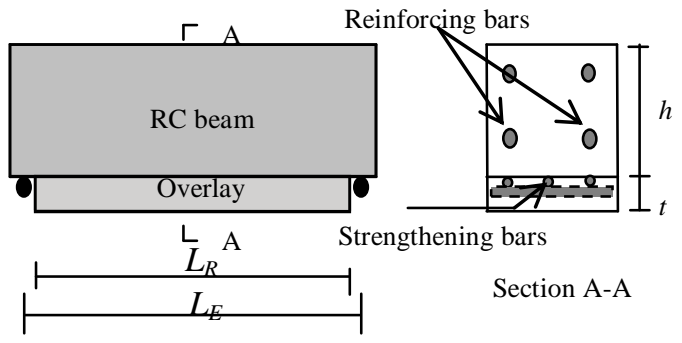

Fig.1 Typical view of overlay strengthening 


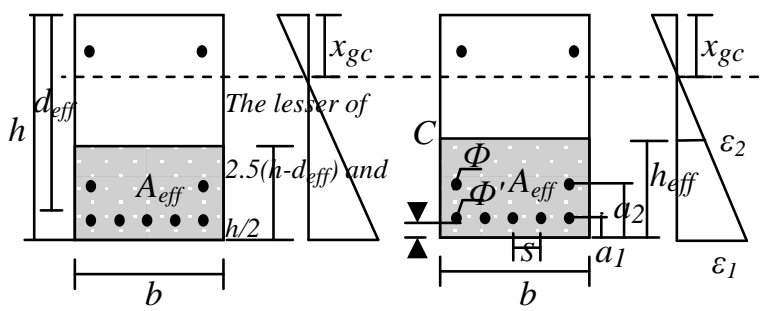

a. EC2 and $C E B-F I P$

b. $C S A$

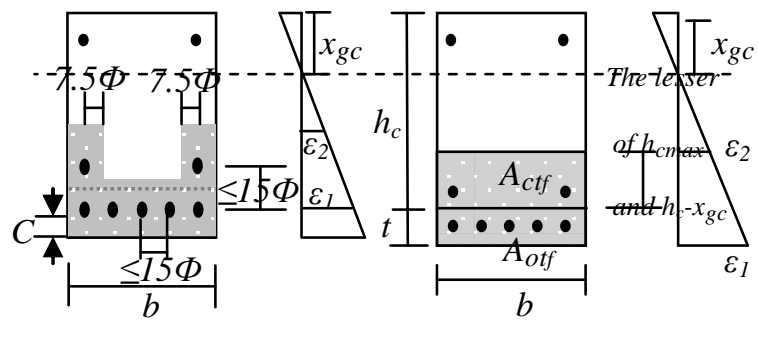

c. $N S$

d. New

$x_{g c}$ : neutral axis depth of cracked section

Fig.2 Effective embedded area 


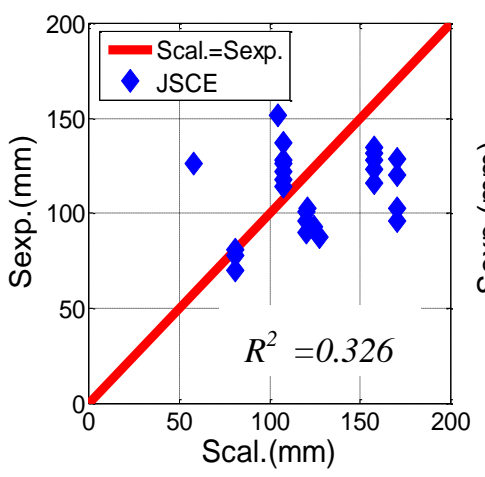

a. JSCE 2007

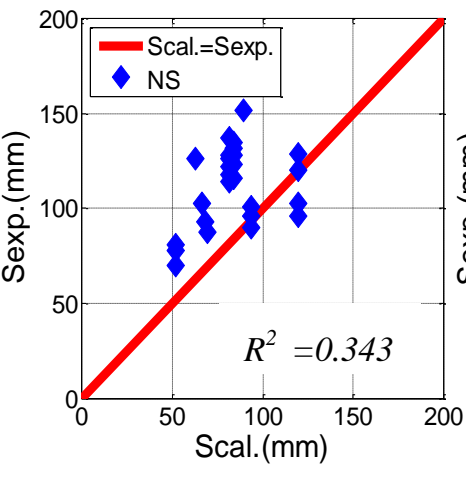

b. NS 3473 E 1992

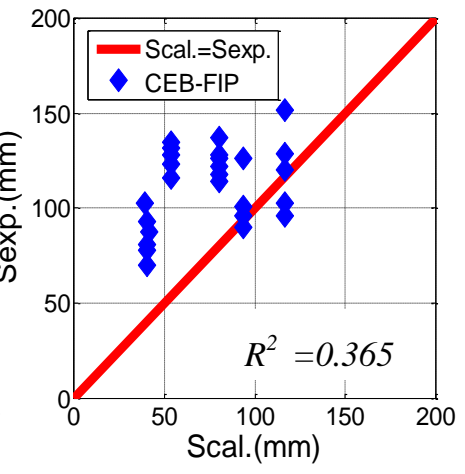

c. CEB-FIP 1990

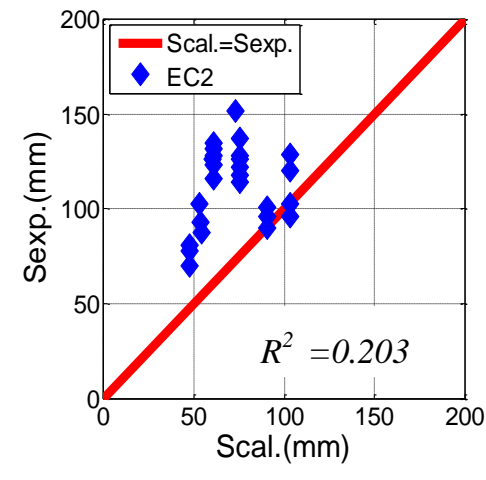

d. Eurocode EC2 provisions

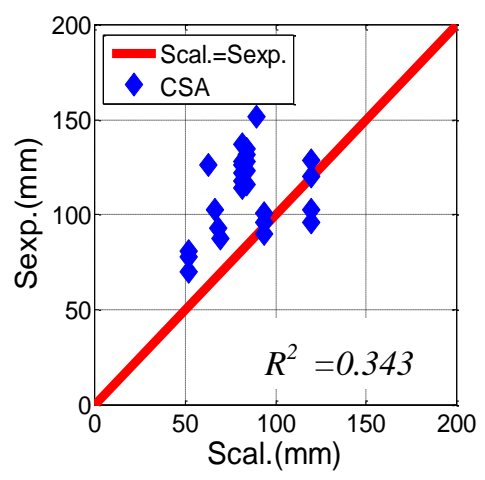

e. CSA S474 2004

Fig. 3 Comparison with original current equations 


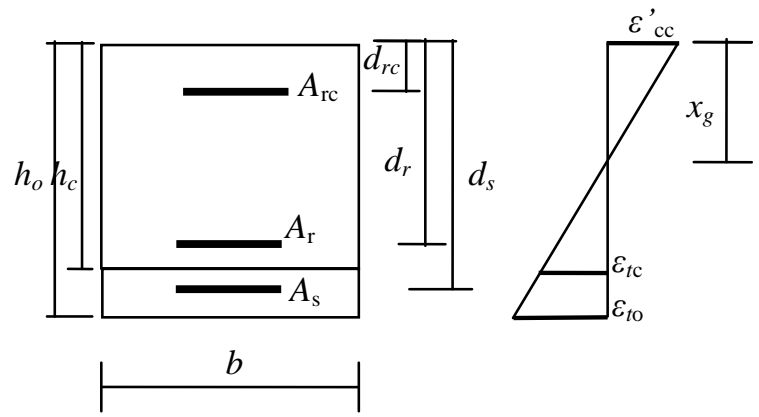

Fig. 4 Sectional analysis of overlay strengthened beam 


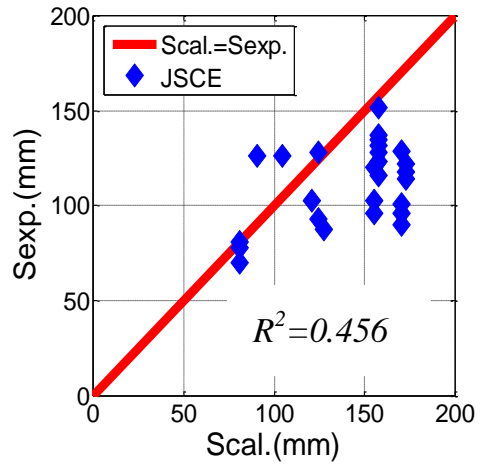

a. JSCE 2007

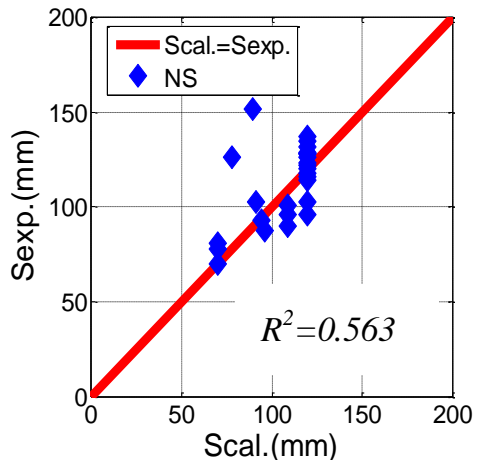

b. NS 3473 E 1992

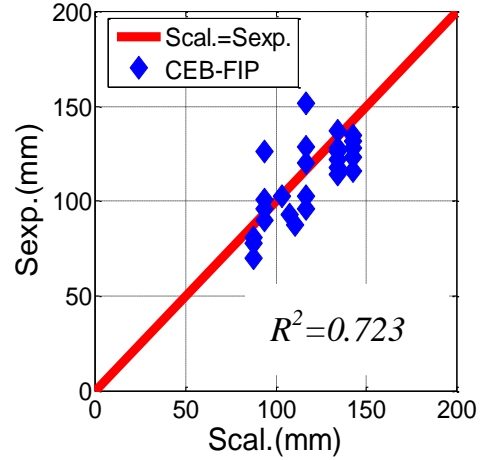

c. CEB-FIP 1990 provisions

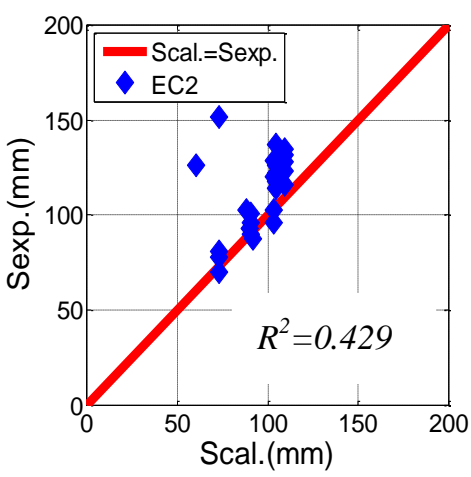

d. Eurocode EC2 provisions

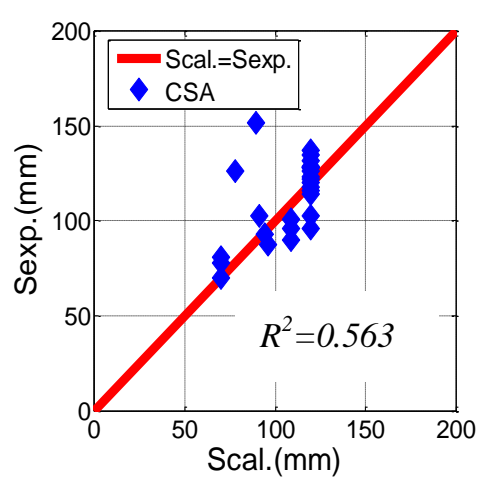

e. CSA S474 2004

Fig. 5 Comparison with modified current equations 


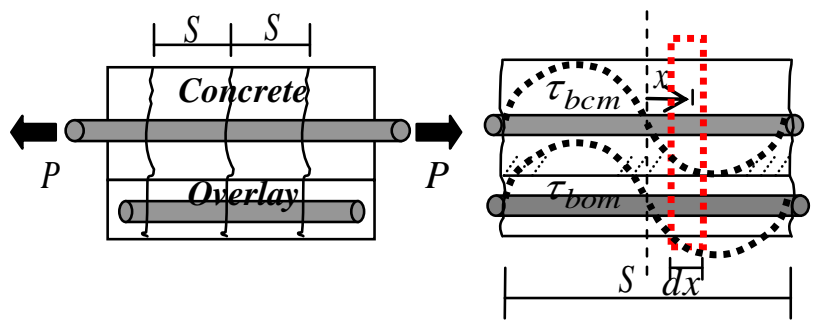

a. uniaxial tension on composite b. bond stress distribution

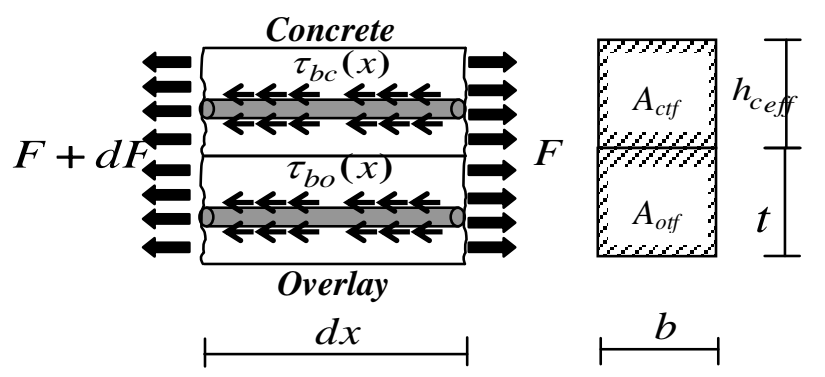

c. free body diagram

Fig.6 Element analysis of composite 


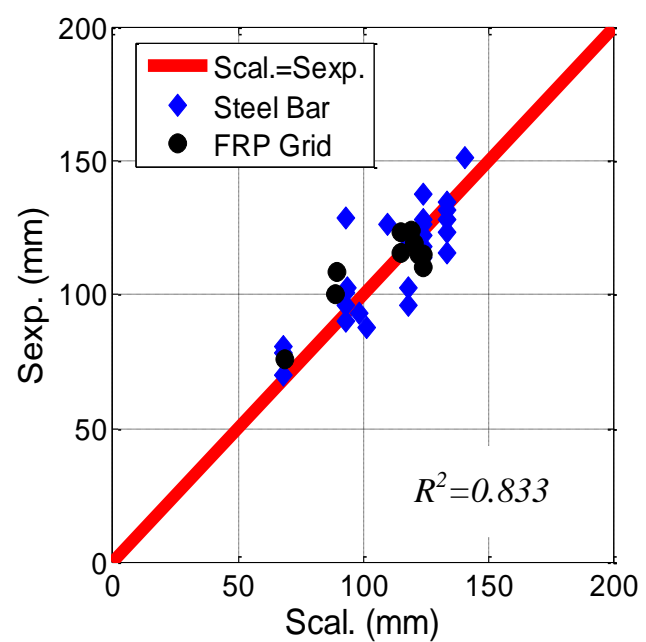

a. Overlay strengthened RC beam

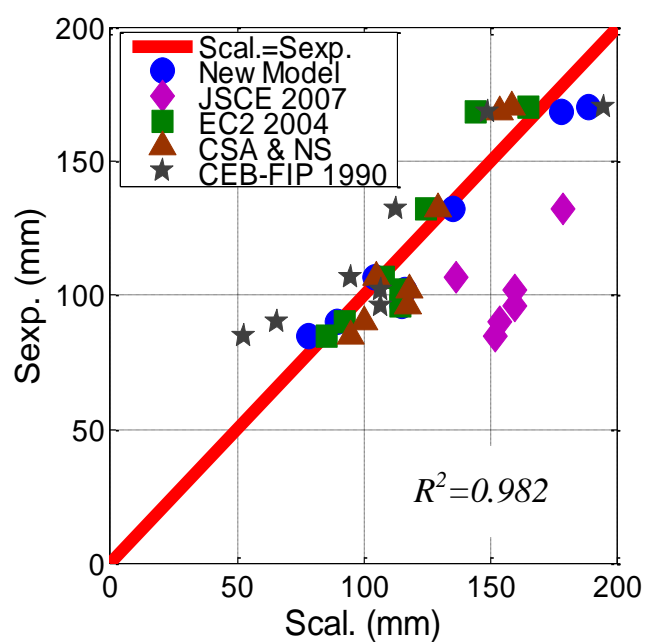

b. Conventional RC beam

Fig.7 Comparison with new proposed model 
Table 1 Calculation with original equations from different codes ${ }^{1)}$

\begin{tabular}{|c|c|c|c|c|c|c|}
\hline \multirow{2}{*}{ Spe. number } & \multicolumn{5}{|c|}{ Calculated average crack spacing (mm) } & \multirow{2}{*}{$\begin{array}{l}\text { Experimental } \\
\text { results }(\mathbf{m m})\end{array}$} \\
\hline & $J S C E$ & $E C 2$ & CSA & $N S$ & $\begin{array}{c}C E B B- \\
F I P\end{array}$ & \\
\hline PS1 & 157.91 & 60.92 & 83.64 & 83.64 & 53.56 & 128.00 \\
\hline PS2 & 157.91 & 60.92 & 83.64 & 83.64 & 53.56 & 135.00 \\
\hline PS3 & 157.91 & 60.92 & 83.64 & 83.64 & 53.56 & 132.00 \\
\hline PS4 & 157.91 & 60.92 & 83.64 & 83.64 & 53.56 & 123.33 \\
\hline PS5 & 157.91 & 60.92 & 83.64 & 83.64 & 53.56 & 116.00 \\
\hline PS6 & 80.96 & 47.78 & 51.55 & 51.55 & 40.34 & 70.00 \\
\hline PS7 & 80.96 & 47.78 & 51.55 & 51.55 & 40.34 & 78.00 \\
\hline PS8 & 80.96 & 47.78 & 51.55 & 51.55 & 40.34 & 80.63 \\
\hline PS9 & 124.7 & 53.84 & 67.98 & 67.98 & 40.44 & 92.86 \\
\hline PS10 & 120.68 & 52.97 & 66.07 & 66.07 & 38.83 & 102.50 \\
\hline PS11 & 127.37 & 54.41 & 69.26 & 69.26 & 41.51 & 87.50 \\
\hline PS12 & 107.65 & 75.42 & 81.73 & 81.73 & 80.41 & 128.41 \\
\hline PS13 & 107.65 & 75.42 & 81.73 & 81.73 & 80.41 & 126.36 \\
\hline PS14 & 107.65 & 75.42 & 81.73 & 81.73 & 80.41 & 137.50 \\
\hline PS15 & 170.63 & 103.09 & 119.64 & 119.64 & 116.83 & 128.91 \\
\hline PS16 & 107.65 & 75.42 & 81.73 & 81.73 & 80.41 & 117.86 \\
\hline PS17 & 170.63 & 103.09 & 119.64 & 119.64 & 116.83 & 120.31 \\
\hline PS18 & 120.31 & 90.47 & 93.52 & 93.52 & 93.46 & 100.78 \\
\hline PS19 & 107.65 & 75.42 & 81.73 & 81.73 & 80.41 & 122.19 \\
\hline PS20 & 170.63 & 103.09 & 119.64 & 119.64 & 116.83 & 102.50 \\
\hline PS21 & 120.31 & 90.47 & 93.52 & 93.52 & 93.46 & 96.25 \\
\hline PS22 & 107.65 & 75.42 & 81.73 & 81.73 & 80.41 & 114.00 \\
\hline PS23 & 170.63 & 103.09 & 119.64 & 119.64 & 116.83 & 96.00 \\
\hline PS24 & 120.31 & 90.47 & 93.52 & 93.52 & 93.46 & 90.00 \\
\hline PS25 & 104.73 & 73.09 & 89.17 & 89.17 & 116.83 & 151.60 \\
\hline PS26 & 58.13 & 60.47 & 63.03 & 63.03 & 93.46 & 126.60 \\
\hline Mean of Scal/Sexp & 1.14 & 0.66 & 0.76 & 0.76 & 0.68 & - \\
\hline $\begin{array}{l}\text { Standard deviation } \\
\text { of Scal/Sexp }\end{array}$ & 0.30 & 0.19 & 0.19 & 0.19 & 0.25 & - \\
\hline
\end{tabular}


Table 2 Calculation with modified equations from different codes and proposed model

\begin{tabular}{|c|c|c|c|c|c|c|c|c|}
\hline \multirow{3}{*}{ Spe. number } & \multicolumn{7}{|c|}{ Calculated average crack spacing (mm) } & \multirow{3}{*}{$\begin{array}{l}\text { Experimental } \\
\text { results }(\mathbf{m m})\end{array}$} \\
\hline & \multirow{2}{*}{$J S C E$} & \multirow{2}{*}{$E C 2$} & \multirow{2}{*}{$C S A$} & \multirow{2}{*}{$N S$} & \multirow{2}{*}{$\begin{array}{c}\text { CEB- } \\
F I P\end{array}$} & \multicolumn{2}{|c|}{ Proposed model } & \\
\hline & & & & & & $S c$ & So & \\
\hline PS1 & 157.91 & 109.13 & 119.71 & 119.71 & 142.83 & 133.71 & 510.18 & 128.00 \\
\hline PS2 & 157.91 & 109.13 & 119.71 & 119.71 & 142.83 & 133.71 & 510.18 & 135.00 \\
\hline PS3 & 157.91 & 109.13 & 119.71 & 119.71 & 142.83 & 133.71 & 510.18 & 132.00 \\
\hline PS4 & 157.91 & 109.13 & 119.71 & 119.71 & 142.83 & 133.71 & 510.18 & 123.33 \\
\hline PS5 & 157.91 & 109.13 & 119.71 & 119.71 & 142.83 & 133.71 & 510.18 & 116.00 \\
\hline PS6 & 80.96 & 73.20 & 69.70 & 69.70 & 87.41 & 68.3 & 183.42 & 70.00 \\
\hline PS7 & 80.96 & 73.20 & 69.70 & 69.70 & 87.41 & 68.3 & 183.42 & 78.00 \\
\hline PS8 & 80.96 & 73.20 & 69.70 & 69.70 & 87.41 & 68.3 & 183.42 & 80.63 \\
\hline PS9 & 124.7 & 90.23 & 94.29 & 94.29 & 107.83 & 98.78 & 270.48 & 92.86 \\
\hline PS10 & 120.68 & 87.92 & 91.20 & 91.20 & 103.55 & 93.68 & 281.58 & 102.50 \\
\hline PS11 & 127.37 & 91.77 & 96.35 & 96.35 & 110.69 & 101.62 & 268.09 & 87.50 \\
\hline PS12 & 124.43 & 104.37 & 119.89 & 119.89 & 134.02 & 124.11 & 401.41 & 128.41 \\
\hline PS13 & 90.88 & 104.37 & 119.89 & 119.89 & 134.02 & 124.11 & 401.41 & 126.36 \\
\hline PS14 & 157.98 & 104.37 & 119.89 & 119.89 & 134.02 & 124.11 & 401.41 & 137.50 \\
\hline PS15 & 170.63 & 103.09 & 119.64 & 119.64 & 116.83 & 93.42 & 378.82 & 128.91 \\
\hline PS16 & 173.32 & 104.37 & 119.89 & 119.89 & 134.02 & 124.11 & 401.41 & 117.86 \\
\hline PS17 & 155.30 & 103.09 & 119.64 & 119.64 & 116.83 & 118.38 & 378.82 & 120.31 \\
\hline PS18 & 170.63 & 90.47 & 108.52 & 108.52 & 93.46 & 93.42 & 294.85 & 100.78 \\
\hline PS19 & 173.32 & 104.37 & 119.89 & 119.89 & 134.02 & 124.11 & 401.41 & 122.19 \\
\hline PS20 & 155.30 & 103.09 & 119.64 & 119.64 & 116.83 & 118.38 & 378.82 & 102.50 \\
\hline PS21 & 170.63 & 90.47 & 108.52 & 108.52 & 93.46 & 93.42 & 294.85 & 96.25 \\
\hline PS22 & 173.32 & 104.37 & 119.89 & 119.89 & 134.02 & 124.11 & 401.41 & 114.00 \\
\hline PS23 & 155.30 & 103.09 & 119.64 & 119.64 & 116.83 & 118.38 & 378.82 & 96.00 \\
\hline PS24 & 170.63 & 90.47 & 108.52 & 108.52 & 93.46 & 93.42 & 294.85 & 90.00 \\
\hline PS25 & 157.98 & 73.09 & 89.17 & 89.17 & 116.83 & 140.53 & 239.75 & 151.60 \\
\hline PS26 & 104.73 & 60.47 & 78.03 & 78.03 & 93.46 & 110.01 & 185.21 & 126.60 \\
\hline HF1 & - & - & - & - & - & 89.71 & 165.23 & 108.80 \\
\hline HF2 & - & - & - & - & - & 119.53 & 546.66 & 124.30 \\
\hline HF3 & - & - & - & - & - & 68.78 & 309.47 & 75.60 \\
\hline HF4 & - & - & - & - & - & 89.08 & 405.63 & 100.30 \\
\hline HF5 & - & - & - & - & - & 120.4 & 540.07 & 119.38 \\
\hline HF6 & - & - & - & - & - & 122.38 & 548.93 & 115.00 \\
\hline HF7 & - & - & - & - & - & 124.35 & 557.79 & 110.40 \\
\hline HF8 & - & - & - & - & - & 124.35 & 557.79 & 115.00 \\
\hline PF1 & - & - & - & - & - & 115.34 & 441.73 & 123.33 \\
\hline PF2 & - & - & - & - & - & 115.34 & 441.73 & 115.90 \\
\hline $\begin{array}{c}\text { Mean of } \\
\text { Scal/Sexp }\end{array}$ & 1.29 & 0.87 & 0.97 & 0.97 & 1.07 & 1.01 & & \\
\hline $\begin{array}{l}\text { Standard } \\
\text { deviation }\end{array}$ & 0.28 & 0.14 & 0.15 & 0.15 & 0.13 & 0.11 & & \\
\hline
\end{tabular}


Table 3 Conventional RC beams with single or double layer tension reinforcement

\begin{tabular}{|c|c|c|c|c|c|c|c|c|}
\hline \multirow[b]{2}{*}{ Num. of layer } & \multirow{2}{*}{$\begin{array}{c}\text { Spe. } \\
\text { number }\end{array}$} & \multicolumn{6}{|c|}{ Calculated average crack spacing (mm) } & \multirow{2}{*}{$\begin{array}{l}\text { Experimental } \\
\text { results }(\mathrm{mm})\end{array}$} \\
\hline & & $J S C E$ & $E C 2$ & $C S A$ & $N S$ & $\begin{array}{c}C E B- \\
F I P\end{array}$ & $\begin{array}{c}\text { New } \\
\text { Model }\end{array}$ & \\
\hline \multirow{4}{*}{ Two layers ${ }^{1)}$} & $C 5$ & 159.87 & 114.72 & 118.07 & 118.07 & 106.88 & 115.29 & 102.00 \\
\hline & c6 & 159.87 & 114.72 & 117.55 & 117.55 & 106.88 & 109.97 & 96.00 \\
\hline & $C 7$ & 154.00 & 92.39 & 100.06 & 100.06 & 65.55 & 89.35 & 90.00 \\
\hline & C8 & 152.11 & 85.46 & 94.84 & 94.84 & 52.71 & 78.57 & 85.00 \\
\hline \multirow{4}{*}{ One layer ${ }^{2)}$} & $C 1$ & 212.52 & 144.56 & 153.73 & 153.73 & 149.19 & 178.35 & 168.50 \\
\hline & $C 2$ & 136.79 & 108.30 & 105.04 & 105.04 & 95.00 & 104.67 & 107.00 \\
\hline & $C 3$ & 179.16 & 124.83 & 129.30 & 129.30 & 112.64 & 135.53 & 132.50 \\
\hline & C4 & 208.98 & 165.15 & 158.90 & 158.90 & 194.71 & 188.93 & 170.45 \\
\hline \multirow{2}{*}{\multicolumn{2}{|c|}{$\begin{array}{c}\text { Mean of Scal/Sexp } \\
\text { Standard deviation of } \\
\text { Scal/Sexp }\end{array}$}} & 1.48 & 1.02 & 1.05 & 1.05 & 0.91 & 1.05 & \\
\hline & & 0.23 & 0.10 & 0.12 & 0.12 & 0.18 & 0.08 & \\
\hline
\end{tabular}

1) without stirrup

2) with stirrup 
Appendix A. Details of overlay strengthened beam samples

\begin{tabular}{|c|c|c|c|c|c|c|c|c|}
\hline \multicolumn{9}{|c|}{ a. Substrate beam } \\
\hline \multirow{2}{*}{ Spe. serial } & \multirow{2}{*}{$\begin{array}{c}\text { Spe. } \\
\text { Number* }\end{array}$} & \multirow{2}{*}{$\begin{array}{c}\begin{array}{c}\text { Efficient } \\
\text { length }\end{array} \\
\begin{array}{c}L_{\text {eff }} \\
(\mathrm{mm})\end{array}\end{array}$} & \multirow{2}{*}{$\begin{array}{c}\text { Width } \\
\begin{array}{c}b \\
(\mathrm{~mm})\end{array}\end{array}$} & \multirow{2}{*}{$\begin{array}{c}\text { Height } \\
\begin{array}{c}h_{c} \\
(\mathrm{~mm})\end{array}\end{array}$} & \multirow{2}{*}{$\begin{array}{c}\begin{array}{c}\text { Shear } \\
\text { Span }\end{array} \\
a(\mathrm{~mm})\end{array}$} & \multicolumn{3}{|c|}{ Concrete } \\
\hline & & & & & & $\begin{array}{c}f_{c}^{\prime}{ }_{c} \\
(\boldsymbol{M P a})\end{array}$ & $f_{c t}(M P a)$ & $E_{c}(M P a)$ \\
\hline \multirow{5}{*}{$\begin{array}{l}\text { (Furuuchi et } \\
\text { al. 2002) }\end{array}$} & $P S 1^{1)}$ & 2200 & 200 & 200 & 800 & 38.1 & 2.60 & $3.04 \mathrm{E}+04$ \\
\hline & PS2 & 2200 & 200 & 200 & 800 & 38.1 & 2.60 & $3.04 \mathrm{E}+04$ \\
\hline & PS3 & 2200 & 200 & 200 & 800 & 38.1 & 2.60 & $3.04 \mathrm{E}+04$ \\
\hline & PS4 & 2200 & 200 & 200 & 800 & 38.1 & 2.60 & $3.04 \mathrm{E}+04$ \\
\hline & PS5 & 2200 & 200 & 200 & 800 & 38.1 & 2.60 & $3.04 \mathrm{E}+04$ \\
\hline \multirow{3}{*}{$\begin{array}{l}\text { (Furuuchi et } \\
\text { al. 2000) }\end{array}$} & PS6 & 1300 & 150 & 200 & 450 & 34.0 & 2.41 & $2.92 \mathrm{E}+04$ \\
\hline & PS7 & 1600 & 150 & 200 & 600 & 34.0 & 2.41 & $2.92 \mathrm{E}+04$ \\
\hline & PS8 & 2000 & 150 & 200 & 800 & 34.0 & 2.41 & $2.92 \mathrm{E}+04$ \\
\hline \multirow{3}{*}{$\begin{array}{c}\text { (Matsumoto } \\
\text { 2010) }\end{array}$} & PS9 & 2270 & 151 & 200 & 785 & 38.7 & 2.63 & $3.06 \mathrm{E}+04$ \\
\hline & PS10 & 2270 & 145 & 200 & 785 & 38.7 & 2.63 & $3.06 \mathrm{E}+04$ \\
\hline & PS11 & 2270 & 155 & 200 & 785 & 38.7 & 2.63 & $3.06 \mathrm{E}+04$ \\
\hline \multirow{12}{*}{$\begin{array}{l}\text { (Satoh and } \\
\text { Kodama } \\
\text { 2005) }\end{array}$} & PS12 & 1380 & 200 & 150 & 460 & 38.0 & 2.70 & $3.37 \mathrm{E}+04$ \\
\hline & PS13 & 1380 & 200 & 150 & 460 & 38.0 & 2.70 & $3.37 \mathrm{E}+04$ \\
\hline & PS14 & 2070 & 200 & 150 & 690 & 38.0 & 2.70 & $3.37 \mathrm{E}+04$ \\
\hline & PS15 & 2070 & 200 & 150 & 690 & 38.0 & 2.70 & $3.37 \mathrm{E}+04$ \\
\hline & PS16 & 2070 & 200 & 150 & 690 & 38.0 & 2.70 & $3.37 \mathrm{E}+04$ \\
\hline & PS17 & 2070 & 200 & 150 & 690 & 38.0 & 2.70 & $3.37 \mathrm{E}+04$ \\
\hline & PS18 & 2070 & 200 & 150 & 690 & 38.0 & 2.70 & $3.37 \mathrm{E}+04$ \\
\hline & PS19 & 2760 & 200 & 150 & 920 & 38.0 & 2.70 & $3.37 \mathrm{E}+04$ \\
\hline & PS20 & 2760 & 200 & 150 & 920 & 38.0 & 2.70 & $3.37 \mathrm{E}+04$ \\
\hline & PS21 & 2760 & 200 & 150 & 920 & 38.0 & 2.70 & $3.37 \mathrm{E}+04$ \\
\hline & PS22 & 2760 & 200 & 150 & 920 & 38.0 & 2.70 & $3.37 \mathrm{E}+04$ \\
\hline & PS23 & 2760 & 200 & 150 & 920 & 38.0 & 2.70 & $3.37 \mathrm{E}+04$ \\
\hline \multirow{4}{*}{$\begin{array}{l}\text { (Zhang } \\
\text { 2009) }\end{array}$} & PS24 & 2760 & 200 & 150 & 920 & 38.0 & 2.70 & $3.37 \mathrm{E}+04$ \\
\hline & PS25 & 1380 & 200 & 150 & 460 & 60.0 & 3.53 & $3.40 \mathrm{E}+04$ \\
\hline & PS26 & 1380 & 200 & 150 & 460 & 60.0 & 3.53 & $3.40 \mathrm{E}+04$ \\
\hline & $H F 1^{2)}$ & 1380 & 200 & 150 & 460 & 43.2 & 2.83 & $3.16 \mathrm{E}+04$ \\
\hline \multirow{3}{*}{$\begin{array}{c}\text { (Yamamoto } \\
2010)\end{array}$} & HF2 & 1380 & 200 & 150 & 460 & 43.2 & 2.83 & $3.16 \mathrm{E}+04$ \\
\hline & HF3 & 1380 & 200 & 150 & 460 & 43.2 & 2.83 & $3.16 \mathrm{E}+04$ \\
\hline & HF4 & 1380 & 200 & 150 & 460 & 43.2 & 2.83 & $3.16 \mathrm{E}+04$ \\
\hline \multirow{4}{*}{$\begin{array}{l}\text { (Yamamoto } \\
\text { et al. 2010) }\end{array}$} & HF5 & 1380 & 200 & 150 & 460 & 41.6 & 2.76 & $3.13 \mathrm{E}+04$ \\
\hline & HF6 & 1380 & 200 & 150 & 460 & 41.6 & 2.76 & $3.13 \mathrm{E}+04$ \\
\hline & HF7 & 1380 & 200 & 150 & 460 & 41.6 & 2.76 & $3.13 \mathrm{E}+04$ \\
\hline & HF8 & 1380 & 200 & 150 & 460 & 41.6 & 2.76 & $3.13 \mathrm{E}+04$ \\
\hline \multirow{2}{*}{$\begin{array}{l}\text { (Furuuchi et } \\
\text { al. 2002) }\end{array}$} & $P F 1^{3)}$ & 2200 & 200 & 200 & 800 & 38.1 & 2.60 & $3.04 \mathrm{E}+04$ \\
\hline & PF2 & 2200 & 200 & 200 & 800 & 38.1 & 2.60 & $3.04 \mathrm{E}+04$ \\
\hline
\end{tabular}

1) $P S$ : PCM with steel bar overlay

2) $\boldsymbol{H F}$ : HPFRCC with FRP grid overlay

3) $\boldsymbol{P F}$ : PCM with FRP grid overlay 
b. Reinforcement in substrate beam

\begin{tabular}{|c|c|c|c|c|c|c|c|}
\hline \multirow[t]{2}{*}{ Spe. serial } & \multirow{2}{*}{$\begin{array}{c}\text { Spe. } \\
\text { number }\end{array}$} & \multicolumn{3}{|c|}{$\begin{array}{l}\text { Compression } \\
\text { reinforcement }\end{array}$} & \multicolumn{3}{|c|}{ Tension reinforcement } \\
\hline & & Num. & $\phi_{r c}(\mathrm{~mm})$ & $d_{r c}(m m)$ & Num. & $\phi_{r}(\mathrm{~mm})$ & $d_{r}(\mathrm{~mm})$ \\
\hline \multirow{5}{*}{$\begin{array}{l}\text { (Furuuchi } \\
\text { et al. 2002) }\end{array}$} & PS1 & 1 & 16 & 40 & 2 & 16 & 160 \\
\hline & PS2 & 1 & 16 & 40 & 2 & 16 & 160 \\
\hline & PS3 & 1 & 16 & 40 & 2 & 16 & 160 \\
\hline & PS4 & 1 & 16 & 40 & 2 & 16 & 160 \\
\hline & PS5 & 1 & 16 & 40 & 2 & 16 & 160 \\
\hline \multirow{3}{*}{$\begin{array}{l}\text { (Furuuchi } \\
\text { et al. 2000) }\end{array}$} & PS6 & 2 & 10 & 35 & 3 & 13 & 165 \\
\hline & PS7 & 2 & 10 & 35 & 3 & 13 & 165 \\
\hline & PS8 & 2 & 10 & 35 & 3 & 13 & 165 \\
\hline \multirow{3}{*}{$\begin{array}{c}\text { (Matsumoto } \\
\text { 2010) }\end{array}$} & PS9 & 1 & 16 & 40 & 2 & 16 & 160 \\
\hline & PS10 & 1 & 16 & 40 & 2 & 16 & 160 \\
\hline & PS11 & 1 & 16 & 40 & 2 & 16 & 160 \\
\hline \multirow{13}{*}{$\begin{array}{l}\text { (Satoh and } \\
\text { Kodama } \\
\text { 2005) }\end{array}$} & PS12 & 2 & 10 & 30 & 2 & 10 & 115 \\
\hline & PS13 & 2 & 10 & 30 & 2 & 10 & 115 \\
\hline & PS14 & 2 & 10 & 30 & 2 & 10 & 115 \\
\hline & PS15 & 2 & 10 & 30 & 2 & 10 & 115 \\
\hline & PS16 & 2 & 10 & 30 & 2 & 10 & 115 \\
\hline & PS17 & 2 & 10 & 30 & 2 & 10 & 115 \\
\hline & PS18 & 2 & 10 & 30 & 2 & 10 & 115 \\
\hline & PS19 & 2 & 10 & 30 & 2 & 10 & 115 \\
\hline & PS20 & 2 & 10 & 30 & 2 & 10 & 115 \\
\hline & PS21 & 2 & 10 & 30 & 2 & 10 & 115 \\
\hline & PS22 & 2 & 10 & 30 & 2 & 10 & 115 \\
\hline & PS23 & 2 & 10 & 30 & 2 & 10 & 115 \\
\hline & PS24 & 2 & 10 & 30 & 2 & 10 & 115 \\
\hline \multirow{3}{*}{$\begin{array}{l}\text { (Zhang } \\
2009)\end{array}$} & PS25 & 2 & 10 & 31 & 2 & 10 & 116 \\
\hline & PS26 & 2 & 10 & 31 & 2 & 10 & 116 \\
\hline & HF1 & 2 & 13 & 30 & 3 & 13 & 120 \\
\hline \multirow{3}{*}{$\begin{array}{l}\text { (Yamamoto } \\
2010)\end{array}$} & HF2 & 2 & 13 & 30 & 2 & 13 & 120 \\
\hline & HF3 & 2 & 13 & 30 & 3 & 13 & 120 \\
\hline & HF4 & 2 & 13 & 30 & 2 & 13 & 120 \\
\hline \multirow{4}{*}{$\begin{array}{l}\text { (Yamamoto } \\
\text { et al. 2010) }\end{array}$} & HF5 & 2 & 13 & 30 & 2 & 13 & 120 \\
\hline & HF6 & 2 & 13 & 30 & 2 & 13 & 120 \\
\hline & HF7 & 2 & 13 & 30 & 2 & 13 & 120 \\
\hline & HF8 & 2 & 13 & 30 & 2 & 13 & 120 \\
\hline \multirow{2}{*}{$\begin{array}{l}\text { (Furuuchi } \\
\text { et al. 2002) }\end{array}$} & PF1 & 1 & 16 & 40 & 2 & 16 & 160 \\
\hline & PF2 & 1 & 16 & 40 & 2 & 16 & 160 \\
\hline
\end{tabular}




\section{c. Overlay properties}

\section{Overlay material Tension reinforcement}

\begin{tabular}{|c|c|c|c|c|c|c|c|c|c|}
\hline Spe. serial & $\begin{array}{c}\text { Spe. } \\
\text { number }\end{array}$ & $\underset{(m m)}{t}$ & $\begin{array}{c}f^{\prime}{ }_{o} \\
(\boldsymbol{M P a})\end{array}$ & $f_{o t}(M P a)$ & $E_{o}(M P a)$ & Num. & $\begin{array}{c}\phi_{s} \\
(m m)\end{array}$ & $d_{s}(m m)$ & $L_{o}(\mathrm{~mm})$ \\
\hline \multirow{5}{*}{$\begin{array}{l}\text { (Furuuchi } \\
\text { et al. 2002) }\end{array}$} & PS1 & 22 & 24.0 & 3.20 & $1.00 \mathrm{E}+04$ & 2 & 6 & 203 & 2000 \\
\hline & PS2 & 22 & 24.0 & 3.20 & $1.00 \mathrm{E}+04$ & 2 & 6 & 203 & 2000 \\
\hline & PS3 & 22 & 24.0 & 3.20 & $1.00 \mathrm{E}+04$ & 2 & 6 & 203 & 2000 \\
\hline & PS4 & 22 & 24.0 & 3.20 & $1.00 \mathrm{E}+04$ & 2 & 6 & 203 & 2000 \\
\hline & PS5 & 22 & 24.0 & 3.20 & $1.00 \mathrm{E}+04$ & 2 & 6 & 203 & 2000 \\
\hline \multirow{3}{*}{$\begin{array}{l}\text { (Furuuchi } \\
\text { et al. 2000) }\end{array}$} & PS6 & 30 & 33.1 & 3.18 & $1.49 \mathrm{E}+04$ & 3 & 6 & 214 & 1200 \\
\hline & PS7 & 30 & 33.1 & 3.18 & $1.49 \mathrm{E}+04$ & 3 & 6 & 214 & 1500 \\
\hline & PS8 & 30 & 33.1 & 3.18 & $1.49 \mathrm{E}+04$ & 3 & 6 & 214 & 1900 \\
\hline \multirow{3}{*}{$\begin{array}{c}\text { (Matsumoto } \\
\text { 2010) }\end{array}$} & PS9 & 22 & 30.0 & 3.35 & $1.45 \mathrm{E}+04$ & 2 & 6 & 203 & 2020 \\
\hline & PS10 & 22 & 30.5 & 3.35 & $1.32 \mathrm{E}+04$ & 2 & 6 & 203 & 2022 \\
\hline & PS11 & 22 & 29.8 & 3.18 & $1.43 \mathrm{E}+04$ & 2 & 6 & 203 & 2006 \\
\hline \multirow{13}{*}{$\begin{array}{l}\text { (Satoh and } \\
\text { Kodama } \\
\text { 2005) }\end{array}$} & PS12 & 22 & 27.6 & 2.89 & $1.21 \mathrm{E}+04$ & 3 & 6 & 153 & 1280 \\
\hline & PS13 & 22 & 27.6 & 2.89 & $1.21 \mathrm{E}+04$ & 3 & 6 & 153 & 1280 \\
\hline & PS14 & 22 & 27.6 & 2.89 & $1.21 \mathrm{E}+04$ & 3 & 6 & 153 & 1970 \\
\hline & PS15 & 30 & 27.6 & 2.89 & $1.21 \mathrm{E}+04$ & 2 & 10 & 155 & 1970 \\
\hline & PS16 & 22 & 27.6 & 2.89 & $1.21 \mathrm{E}+04$ & 3 & 6 & 153 & 1970 \\
\hline & PS17 & 30 & 27.6 & 2.89 & $1.21 \mathrm{E}+04$ & 2 & 10 & 155 & 1970 \\
\hline & PS18 & 30 & 27.6 & 2.89 & $1.21 \mathrm{E}+04$ & 3 & 10 & 155 & 1970 \\
\hline & PS19 & 22 & 27.6 & 2.89 & $1.21 \mathrm{E}+04$ & 3 & 6 & 153 & 2660 \\
\hline & PS20 & 30 & 27.6 & 2.89 & $1.21 \mathrm{E}+04$ & 2 & 10 & 155 & 2660 \\
\hline & PS21 & 30 & 27.6 & 2.89 & $1.21 \mathrm{E}+04$ & 3 & 10 & 155 & 2660 \\
\hline & PS22 & 22 & 27.6 & 2.89 & $1.21 \mathrm{E}+04$ & 3 & 6 & 153 & 2660 \\
\hline & PS23 & 30 & 27.6 & 2.89 & $1.21 \mathrm{E}+04$ & 2 & 10 & 155 & 2660 \\
\hline & PS24 & 30 & 27.6 & 2.89 & $1.21 \mathrm{E}+04$ & 3 & 10 & 155 & 2660 \\
\hline \multirow{3}{*}{$\begin{array}{l}\text { (Zhang } \\
2009 \text { ) }\end{array}$} & PS25 & 30 & 57.4 & 3.80 & $2.34 \mathrm{E}+04$ & 2 & 10 & 170 & 1280 \\
\hline & PS26 & 30 & 57.4 & 3.80 & $2.34 \mathrm{E}+04$ & 3 & 10 & 170 & 1280 \\
\hline & HF1 & 15 & 57.4 & 3.80 & $2.34 \mathrm{E}+04$ & 2 & $4 \times 6^{*}$ & 154 & 1280 \\
\hline \multirow{3}{*}{$\begin{array}{c}\text { (Yamamoto } \\
\text { 2010) }\end{array}$} & HF2 & 15 & 42.5 & 4.50 & $1.14 \mathrm{E}+04$ & 2 & $4 \times 6^{*}$ & 154 & 1280 \\
\hline & HF3 & 15 & 42.5 & 4.50 & $1.14 \mathrm{E}+04$ & 4 & $4 \times 6^{*}$ & 154 & 1280 \\
\hline & HF4 & 15 & 42.5 & 4.50 & $1.14 \mathrm{E}+04$ & 4 & $4 \times 6^{*}$ & 154 & 1280 \\
\hline \multirow{4}{*}{$\begin{array}{l}\text { (Yamamoto } \\
\text { et al. 2010) }\end{array}$} & HF5 & 10 & 23.9 & 4.50 & $1.14 \mathrm{E}+04$ & 2 & $4 \times 4.5^{*}$ & 152 & 1280 \\
\hline & HF6 & 15 & 23.9 & 4.50 & $1.14 \mathrm{E}+04$ & 2 & $4 \times 4.5^{*}$ & 157 & 1280 \\
\hline & HF7 & 20 & 23.9 & 4.50 & $1.14 \mathrm{E}+04$ & 2 & $4 \times 4.5^{*}$ & 162 & 1280 \\
\hline & HF8 & 20 & 23.9 & 4.50 & $1.14 \mathrm{E}+04$ & 2 & $4 \times 4.5^{*}$ & 157 & 1280 \\
\hline \multirow{2}{*}{$\begin{array}{l}\text { (Furuuchi } \\
\text { et al. 2002) }\end{array}$} & PF1 & 22 & 24.0 & 3.20 & $1.00 \mathrm{E}+04$ & 3 & $4 \times 5^{*}$ & 203 & 2100 \\
\hline & PF2 & 22 & 24.0 & 3.20 & $1.00 \mathrm{E}+04$ & 3 & $4 \times 5^{*}$ & 203 & 2100 \\
\hline
\end{tabular}

* Width x Height of FRP grid longitudinal cross section 
Appendix B. Details of beam samples with single or multilayered-reinforcement

\begin{tabular}{|c|c|c|c|c|c|c|c|c|c|}
\hline \multicolumn{10}{|c|}{ a. Concrete and compression reinforcement } \\
\hline \multirow{2}{*}{ Spe. serial } & \multirow{2}{*}{$\begin{array}{c}\text { Spe. } \\
\text { number }\end{array}$} & \multirow{2}{*}{$\begin{array}{c}\text { Width } \\
\begin{array}{c}B \\
(\mathrm{~mm})\end{array}\end{array}$} & \multirow{2}{*}{$\begin{array}{c}\text { Height } \\
\begin{array}{c}H \\
(\mathrm{~mm})\end{array}\end{array}$} & \multicolumn{3}{|c|}{ Concrete } & \multicolumn{3}{|c|}{$\begin{array}{l}\text { Compression } \\
\text { reinforcement }\end{array}$} \\
\hline & & & & $\begin{array}{c}f_{c}^{\prime} \\
(\boldsymbol{M P a})\end{array}$ & $f_{t}^{\prime}(M P a)$ & $E_{c}(M P a)$ & Num. & $\begin{array}{c}\phi \\
r c(m m)\end{array}$ & $d_{r c}(m m)$ \\
\hline $\begin{array}{l}\text { (Furuuchi } \\
\text { et al. 2002) }\end{array}$ & $C 1^{1)}$ & 200 & 200 & 38.1 & 2.60 & $3.04 \mathrm{E}+04$ & 1 & 16 & 40 \\
\hline $\begin{array}{l}\text { (Furuuchi } \\
\text { et al. 2000) }\end{array}$ & $C 2$ & 150 & 200 & 34.0 & 2.41 & $2.92 \mathrm{E}+04$ & 2 & 10 & 35 \\
\hline $\begin{array}{l}\text { (Matsumoto } \\
\text { 2010) }\end{array}$ & $C 3$ & 151 & 200 & 38.7 & 2.63 & $3.06 \mathrm{E}+04$ & 1 & 16 & 40 \\
\hline $\begin{array}{c}\text { (Satoh and } \\
\text { Kodama } \\
\text { 2005) }\end{array}$ & $C 4$ & 200 & 150 & 38.0 & 2.70 & $3.37 \mathrm{E}+04$ & 2 & 10 & 30 \\
\hline & C5 & 150 & 300 & 29.1 & 2.17 & $2.77 \mathrm{E}+04$ & - & - & - \\
\hline (Zhao and & C6 & 150 & 300 & 29.1 & 2.17 & $2.77 \mathrm{E}+04$ & - & - & - \\
\hline Miagala & $C 7$ & 150 & 300 & 31.3 & 2.28 & $2.84 \mathrm{E}+04$ & - & - & - \\
\hline & C8 & 150 & 300 & 31.3 & 2.28 & $2.84 \mathrm{E}+04$ & - & - & - \\
\hline
\end{tabular}

1) $C$ : Conventional $\mathrm{RC}$ beams

\begin{tabular}{|c|c|c|c|c|c|c|c|}
\hline \multicolumn{8}{|c|}{ b. Tension reinforcement } \\
\hline \multirow{2}{*}{ Spe. serial } & \multirow{2}{*}{$\begin{array}{c}\text { Spe. } \\
\text { number }\end{array}$} & \multicolumn{3}{|c|}{ 1st tension reinforcement } & \multicolumn{3}{|c|}{ 2st tension reinforcement } \\
\hline & & Num. & $\phi_{r I}(m m)$ & $d_{r I}(m m)$ & Num. & $\phi_{r 2}(m m)$ & $d_{r 2}(m m)$ \\
\hline $\begin{array}{l}\text { (Furuuchi } \\
\text { et al. 2002) }\end{array}$ & $C 1$ & 1 & 16 & 40 & - & - & - \\
\hline $\begin{array}{l}\text { (Furuuchi } \\
\text { et al. 2000) }\end{array}$ & $C 2$ & 2 & 10 & 35 & - & - & - \\
\hline $\begin{array}{c}\text { (Matsumoto } \\
2010 \text { ) }\end{array}$ & $C 3$ & 1 & 16 & 40 & - & - & - \\
\hline $\begin{array}{l}\text { (Satoh and } \\
\text { Kodama } \\
\text { 2005) }\end{array}$ & $C 4$ & 2 & 10 & 30 & - & - & - \\
\hline & C5 & 2 & 13 & 215 & 2 & 13 & 265 \\
\hline (Zhao and & C6 & 2 & 13 & 240 & 2 & 13 & 265 \\
\hline $\begin{array}{l}\text { Maruyama } \\
1994)\end{array}$ & $C 7$ & 2 & 19 & 240 & 2 & 13 & 265 \\
\hline & C8 & 2 & 22 & 248 & 2 & 13 & 265 \\
\hline
\end{tabular}

